\author{
Monika Pokorska-Iwaniuk* \\ Wydział Neofilologii, Zakład Bałtologii, Lituanistyka \\ UAM w Poznaniu \\ https://orcid.org/0000-0002-7826-8731
}

\title{
Fascynacje literackie Maironisa
}

Streszczenie: Jonas Mačiulis-Maironis, bohater artykułu, to litewski poeta końca XIX i początku XX wieku. Jego dorobek literacki jest bardzo bogaty i obejmuje zbiór tekstów, wierszy i dramatów, a także teksty publicystyczne i rozprawy akademickie. Był nie tylko poetą, ale także kapłanem, profesorem akademickim, a przede wszystkim osobą publiczną, wchodząc do ścisłej elity intelektualnej Litwy XX wieku. Był bardzo szanowany przez litewskie społeczeństwo, nazywany wręcz przywódcą narodu litewskiego. Dlatego jego praca literacka i literackie fascynacje stanowią temat, który podejmowało wielu badaczy. Warto wspomnieć o jego kontaktach i przyjaźni z poetami, pisarzami i naukowcami tego czasu, głównie z Antanasem Baranauskasem. Pozostawał pod wpływem polskiej kultury i literatury, a jego wiersze ujawniły bliskie relacje z polskimi autorami: Mickiewiczem, Asnykiem, Polem. Jego poezja jest wciąż żywa.

Słowa-klucze: Maironis, literatura litewska, kultura i dziedzictwo, romantyzm i pozytywizm na Litwie

Monika Pokorska-Iwaniuk - dr, adiunkt w Zakład Bałtologii Instytutu Językoznawstwa Uniwersytetu Adama Mickiewicza w Poznaniu; literaturoznawczyni, autorka licznych studiów historycznoliterackich oraz książki Twórczość liryczna Maironisa, Poznań 2018. 


\section{Maironis's literary fascinations}

Summary: Jonas Mačiulis-Maironis - a Lithuanian poet of the end of the 19th century and beginning of the 20th century. His literary output is very rich and includes the collection of lyrics, poems and dramas and also journalistic and academic writings. He was not only a poet but also a priest, an academic professor and most of all a public person. A member of the 20th century Lithuanian elite. He was well known, esteemed, and called a leader of Lithuanian nation. For this reason his literary fascinations were analyzed by many scholars. His contacts and friendship with many poets, writers and scientists of this time, mainly with Antanas Baranauskas also deserve attention. He was under the influence of Polish culture and literature and his verses reveal close relations with Polish authors: Mickiewicz, Asnyk, Pol. His poetry is still vivid.

Key words: Maironis, Lithuanian literature, culture and heritage, Romanticism and Positivism in Lithuania

\section{Maironio literatūriniai žavėsiai}

Lietuvoje Maironio kūryba domejosi ir domisi visi, rašytojai, poetai, kritikai ir literatūros istorikai. Atrodo, kad apie ši poetą pasakyta jau viskas, pradedant nuo 1891 metų, kai pasirodè Maironio kūrinių pirmoji recenzija. Tačiau pasirodo, kad nepaisant tokio didelio apie kūrèją balsu kiekio, tik keletas iš ju išeina už proginių pasisakymu ar škicu rèmu, o šio poeto kūrybos analizès sutelktos tik j išrinktuosius kūrinius, visiškai praleidžiant šio lietuvių kūrèjo susidomèjimą lenkų ir europietiška literatūra.

Lenkijoje Maironis beveik nežinomas poetas. XX amžiaus pradžioje jo veikalų vertimais su ivvairiu pasisekimu užsiiminèjo Stefania Jabłońska, Julia Wichert-Kajruksztisowa. Po antrojo pasaulinio karo keletas Maironio eilèraščių paminèta tik 1973 metais Zygmundo Stoberskio Lietuvių literatūros antologijoje.

To aiškiai nepakanka ir panašu, kad tą maironiškos kūrybos pažinimo trūkumą reikia nuolat pildyti, ar bent jau padaryti Maironi-poetą mokslinès srities obiektu.

Straipsnyje būtina parodyti charakteringas šio poeto gyvenimo ir kūry- 
bos ypatybes. Svarbu būtu pagilinti tyrimus apie poeto gyvenimo pasirinkimus, ivairius gyvenimo vaidmenis. Kai kurie jo rašybos bruožai betarpiškai susiję su jo skaitiniais, gyvenimo principais ir isipareigojimais, ir pagaliau su troškimais ir niekada neišsipildžiusiomis svajonèmis. Jo literatūriniai susižavejjimai Baranausku ir Mickevičiumi ir tuo pačiu domèjimasis Samuelio Smiles kūryba, parodo ji kaip žmogu, pilną ne tik romantiniu prieštaravimu ir vidiniu nesutarimu tarp savirealizacijos ir pasitenkinimo, bet ir žmogu gana tipišką tiems laikams, tikriausiai linkusi i vidutinybes.

Straipsnyje ketinama parodyti Maironio kūrybos vietą pasaulyje ir europietiškos literatūros fone bei poeto ryši su lenkų kultūra ir literatūra. Daugiau ar mažiau ryškus Poeto ryšiai su Mickevičiaus, Polo, Asnyko poezija, leidžia sukurti i̇domią studiją literatūrinès komparatyvistikos srityje.

Raktiniai žodžiai: Maironis, lietuvių literatūra, kultūrinis paveldas, romantizmas ir pozityvizmas Lietuvoje.

„Poetai, būna dviejų rūšių: vieni miršta dar gyvi būdami, kiti nemiršta niekad" (Poeci należą do dwóch kategorii: jedni umierają będąc jeszcze żywymi, inni nie umierają nigdy). Te słowa Borysa Pasternaka przytoczył w swoim artykule o Maironisie znany litewski poeta Tomas Venclova ${ }^{1}$. Bez wątpienia tego wielkiego litewskiego poetę można zaliczyć do kategorii twórców ciągle obecnych w literaturze litewskiej. Jest postacią czczoną i szanowaną przez zwykłych, „codziennych” czytelników, a analizy jego twórczości, dość jednostronne do 1988 roku, stają się obecnie wieloaspektowe.

Maironis - właściwie Jonas Mačiulis - to pseudonim twórczy litewskiego poety, dramaturga, wykładowcy uniwersyteckiego, publicysty, księdza, który tworzył w końcu XIX i na początku XX wieku. Znany jako poeta i szanowany jako ksiądz, Maironis jeszcze za życia doświadczył uroków, ale i niebezpieczeństw sławy, okrzyknięty został wieszczem narodowym, a jego poezja była i jest recytowana i śpiewana niemalże w każdym zakątku kra-

1 T. Venclova, Laimei Maironis, [w:] Vilties formos, Vilnius 1992, s. 288. 
ju. Był doktorem teologii, profesorem Uniwersytetu Litewskiego, rektorem Kowieńskiego Seminarium Duchownego, prałatem Kapituły Kowieńskiej, honorowym kanonikiem Katedry mohylewskiej² .

Jego spuścizna literacka obejmuje utwory poetyckie, dramatyczne, również prace z zakresu teologii, historii, socjologii, literatury (między innymi wykłady o Kristijonasie Donelaitisie czy Antanasie Baranauskasie), a także szkice krytyczne i teksty publicystyczne ${ }^{3}$.

Maironisa fascynacja literaturą zaczęła się już w dzieciństwie, w domu rodzinnym. Nie mając potwierdzenia w konkretnych źródłach, przypuszcza się jedynie, jakie pozycje czytelnicze mogły znaleźć się u Mačiulisów. Wiadomo, że w okresie od 1864 roku, kiedy to wprowadzono na Litwie zakaz druku czcionką łacińską, dostęp do książek był ograniczony, jednakże częste podróże ojca w interesach do Kowna, czy nawet odległego Krakowa, jak również kontakty z knygniašiai (nosiciele ksiązek) pomagały w dotarciu do słowa pisanego. Przypuszczalnie, w bibliotece rodzinnej nie brakowało pozycji Motiejusa Valančiusa, biskupa żmudzkiego, autora zaprzyjaźnionego z Mačiulisami². Czytano prace Simonasa Daukantasa, Laurynasa Ivinskisa, wiersze Kajetonasa Aleknavičiusa, Antanasa Strazdasa. Dwujęzyczność rodziny Mačiulisów, oczytanie, ciekawość świata i możliwość zapoznawania się z aktualnymi tendencjami w różnych dziedzinach kultury europejskiej zaowocowało rozwijaniem pasji literackich u młodego poety i rozbudziło fascynację literaturą polską i polskimi twórcami.

Naukę w gimnazjum kowieńskim Maironis rozpoczął w 1873 roku5. Mačiulis obracał się więc w kręgach szlacheckich. Uczył się przeciętnie albo i gorzej niż przeciętnie, skoro dwukrotnie powtarzał rok. W początkowych

2 Patrz: Sirius, Zgon Maironisa, „Przegląd Wileński” 1932, nr 13.

3 Wszystkie liryki, poematy i dramaty Maironisa, jak również jego teksty krytyczne i publicystyczne zostały wydane w trzytomowym zbiorze Raštai (Pisma zebrane), tom I i II 1988 rok, tom III (pirmoji i antroji knyga) 1992 rok. Szczegółowy wypis wszystkich dzieł Maironisa można znaleźć w pracy: R. Adomavičius, Maironio raštų bibliografija (1883-1989), Vilnius 1990.

4 W książce M. Valančiusa pt. Palangos Juze wymienione jest nazwisko Aleksandrasa Mačiulisa. Patrz: V. Zaborskaite, dz. cyt., s. 16.

5 Po powstaniu styczniowym w guberni kowieńskiej pozostały tylko dwa czynne gimnazja - w Szawlach i Kownie. Rodzice, głównie z powodu łatwiejszego dojazdu, wybrali gimnazjum w Kownie, mimo że było ono droższe. Była to dobra szkoła, kontynuująca tradycje i pamiętająca wykłady Adama Mickiewicza, co prawda zamknięta po powstaniu listopado- 
latach interesował się przedmiotami ścisłymi, dopiero w szóstej klasie napisał kilka wierszy po polsku, niestety te pierwsze strofy gdzieś zaginęły lub zostały zniszczone przez samego autora. Zajęcia w szkole prowadzone były po rosyjsku, uczniowie mieli obowiązek studiowania literatury rosyjskiej (program był tak ułożony, że studenci w niższych i wyższych klasach czytali Żukowskiego, Kryłowa, Puszkina, Lermontowa, Gogola) ${ }^{6}$. Nie ulega jednak wątpliwości, iż przez cały czas w gimnazjum, a i później w seminarium, na rozwój duchowy i umysłowy Maironisa miała wpływ kultura polska, a Mickiewicz i Słowacki byli już wtedy ulubionymi autorami, których romantyczna poezja kształtowała wybory twórcze litewskiego poety.

Lata nauki w seminarium od 1884 roku były dla Maironisa okresem wytężonej pracy. Do Kowna docierały już pierwsze wiadomości o budzącym się ruchu odrodzenia narodowego, o wychodzących pierwszych litewskich pismach: „Aušra” czy „Šviesa”. Swój debiutancki wiersz pt. Lietuvos vargas poeta wydrukował właśnie w piśmie „Aušra” w 1885 roku. Coraz bardziej w poecie ożywała chęć do tworzenia w języku narodowym. Tymczasem - tu pojawia się zarzewie kolejnego konfliktu - w seminarium uczniowie zanurzeni byli przede wszystkim w polskiej kulturze i polskim języku. Były co prawda zajęcia z języka litewskiego, które prowadził Antanas Baranauskas, ale równocześnie istniał wyraźny, choć zwyczajowy zakaz komunikowania się w tym języku z przełożonymi czy prowadzenia prywatnych rozmów między sobą.

Maironis interesował się historią Litwy, przestudiował dzieła Simonasa Daukantasa, Teodora Narbutta, Józefa Ignacego Kraszewskiego, a w efekcie przemyśleń nad tymi lekturami powstała praca pt. Apsakymai apie Lietuvos praeiga, wydana w 1891 roku, w której opisane są wydarzenia historyczne od XII do początku XIX wieku. We wstępie Maironis krótko streszcza czasy Litwy przedchrześcijańskiej, mówi o pochodzeniu, wierze i sposobie życia dawnych Litwinów 7 . W tym okresie zajął się też publicystyką i napisał między

wym, ale reaktywowana w 1863 roku na nowym miejscu, po połączeniu z gimnazjum w Krożach (Kražiai). Szkoła miała dobre zaplecze naukowe, należycie wyposażone gabinety, ciekawe zbiory medali, bogatą bibliotekę powstałą z połączenia zbiorów zamkniętych placówek w Kiejdanach (Kédainiai) i Poniewieżu (Panevėžys). Patrz: V. Zaborskaitė, dz. cyt., s. 21.

6 Tamże, s. 25.

7 Maironis, Apsakymai apie Lietuvos praeiga, [w:] tenże, Raštai, t. III, Vilnius 1992, s. $439-578$. 
innymi artykuł poświęcony serbołużyckiemu działaczowi narodowemu, etnografowi Janowi Smolerowi, który został zamieszczony w 1885 roku w czasopiśmie „Aušra”. Od 1887 roku podjął współpracę z pismem „Šviesa”, którego redaktorem był bliski przyjaciel Maironisa - Antanas Vytartas. Tutaj zamieścił między innymi artykuł Žodis prie lietuviu, mylinčiu savo tèvynę (Stowo do Litwinów kochajacych swoją ojczyznę, 1888) i wiersz Broliai ị darba (Bracia do pracy) nawiązujący do Mickiewiczowskiego przesłania z Ody do młodo$s^{\prime} c i^{9}$. Wszystkie prace podpisywał pseudonimami Stanislovas Zanavykas albo Stanislovas Zvalionis ${ }^{10}$.

W okresie nauki w seminarium Maironis zafascynowany był postacią i twórczością Antanasa Baranauskasa. Można zaryzykować stwierdzenie, że dla młodego poety Baranauskas był przywódca duchowym, nauczycielem studiów literackich. Maironis będąc w Akademii zaprzyjaźnił się z Ludwikiem Biesiekierskim, który przyjechał do Petersburga z Kalisza. Obydwu studentów połączyło zainteresowanie literaturą. Biesiekierski, który prawdopodobnie nie znał języka litewskiego, przy pomocy Maironisa przetłumaczył Borek oniksztyński, uważa się, że to maironisowskie tłumaczenie jest jednym z lepszych.

Przez lata nauki w seminarium i potem w akademii duchownej zafascynowanie Maironisa Baranauskasem nie słabło, ale dopiero w czasach nauki w Akademii Duchownej, od 1888 roku udało się Maironisowi spotkać z Baranauskasem. Tak w 1923 roku wspominał Maironis:

Kadangi Baranauskas mirè jau pradžioj šio šimtmečio 1902 m., tai daugelis mūsų ji gerai atsimena, gal net yra matęs. Man teko ji arčiau pažinti, net laiškais susirašinèti, susirašinèti lenkiškai, kas dabar išrodo istabu [...] pirmą sykį man teko su juo arti susidurti, važiuojant mokintis i Peterburgo aukštą akademiją... ${ }^{11}$

8 Tenże, Jonas Ernestas Smoleris, [w:] tenże, Raštai, t. III, Vilnius 1992, s. 582-602.

9 V. Zaborskaite, dz. cyt., s. 61.

10 Stanislovas to „dirmavonès vardas” - imię z bierzmowania Mačiulisa - to drugie nazwisko natomiast kojarzy się ze wsią Žvalionis pod Betygalą, w której mieszkali krewni Maironisa. Patrz: J. Tumas, dz. cyt., s. 19.

11 Maironis, Paskaita apie Vysk. Ant. Baranauska, [w:] Maironis, Raštai, t. III, Vilnius 1992, s. 750. 
(Jako że Baranauskas umarł na początku tego stulecia, w 1902 roku, tak też wielu z nas dobrze go pamięta, a może i widziało. Mi udało się z nim bliżej poznać, gdy wyjechałem studiować do Akademii duchownej w Petersburgu. Pisaliśmy też do siebie listy, pisaliśmy po polsku, co dzisiaj może wydaje się dziwne.)

Niestety kontakt z Baranauskasem, gdy ten był już biskupem sejneńskim, nieoczekiwanie został urwany, gdy Maironis napisał do niego list po litewsku, „Susirašinėjimas nutrukęs, kai vieną kartą Baranauskui, jau Seinų vyskupui, Maironis parašęs laišką lietuviškai"12 (korespondencja ustała, gdy pewnego razu Maironis napisał list do Baranauskasa, wtedy już biskupa sejneńskiego, po polsku). Taką informację podaje Regina Mikšytė w pracy Baranauskas ir Maironis.

W późniejszym okresie stosunek Maironisa do Baranauskas i jego twórczości był mniej pozytywny, wręcz stawał się szyderczy i nieprzychylny. I ten jego krytycyzm wraz z wiekiem i upływem czasu potęgował się. W 1923 roku na wykładach z literatury nie szczędził gorzkich słów krytyki o sejneńskim biskupie:

[...] jo raštiškas palikimas ne per didelis, o tai dẻl to, kad tas žmogus, turédamas devynius talentus, blaškèsi nuo vieno dalyko prie kito ir nei vieno talento nesunaudojo tiek, kiek būtu galèjęs [...] o tuo tarpu jo vardą tik vienas Anykščių šilelis išvaduos nuo užmiršimo ${ }^{13}$.

([...] jego dorobek twórczy jest niewielki, a to dlatego, że ten człowiek, który został obdarzony dziewięcioma talentami, dumny był ze wszystkich, i każdy próbował rozwijać, a żadnego nie wykorzystał jak należy [...] i tak tez tylko Borek oniksztyński chroni jego imię od zapomnienia.)

O Borku pisał między innymi, że to ,perlas mūsų poezijoje”14 (perła naszej poezji), poetycki, żywy opis odznaczający się bogactwem słownictwa,

12 R. Mikšytè, Baranauskas ir Maironis, [w:] Literatūra ir kalba, t. XXI, Vilnius 1990, S. 163.

13 Maironis, Paskaita apie Vysk. Ant. Baranauska [w:] Maironis, Raštai, t. III, Vilnius 1992, s. 751.

14 Tamże, s. 756. 
przepełniony uczuciem, który nie zostanie zapomniany, ale równocześnie dodawał:

Šilelio aprašymas kaip kiekvienas aprašymas poezijoje labai nedèkingas; labai sunku čia išvengti nuobodumo ir ilgiau sulaikyti atidą; poezija reikalauja daugiau akcijos, jausmo, atido itempimo....15

(Opis borku, tak jak i każdy opis w poezji, bardzo to temat niewdzięczny. Bardzo trudno przykuć uwagę czytelnika, ustrzec się ogarniającego nas znużenia. Poezja potrzebuje więcej akcji, uczucia, uwagi, napięcia.)

Czy ten Maironisowski krytycyzm był podyktowany dawnymi zaszłościami, kiedy to Baranauskas niezbyt pozytywnie, a raczej obojętnie potraktował próby pisarskie młodego poety, wtedy jeszcze słuchacza akademickich wykładów? Jeszcze w trakcie nauki w akademii Maironis napisał krótki poemat Lietuva (Litwa). Rękopis tego dzieła młody poeta przekazał do oceny Antanasowi Baranauskasowi, a ten, jak podaje Juozas Tumas Vaizgantas, dosyć obojętnie zbył młodzieńca takim nic nie znaczącym, a może trochę szyderczym uśmieszkiem ${ }^{16}$.

Sam Maironis po latach tak wspomina to zdarzenie:

[...] pravažiuodamas jam j̇teikiau tuomet savo pirmuosius eiliu méginimus, kuriuose aprašinejau Lietuvą ir kuriụ nespausdinau ir nemanau spausdinti, nes jie labai silpnučiai. Baranauskas tai jau ju labai nepeikè Ir padrąsino talento neužkasti ${ }^{17}$.

([...] dałem mu (Baranauskasowi) do przejrzenia swoje pierwsze strofy, w którym opisałem Litwę i których to nie drukowałem i nie miałem zamiaru drukować, gdyż były bardzo słabiutkie. Baranauskas nawet zbytnio nie ganił i radził talentu nie zmarnować.)

15 Tamże, s.755.

16 J. Tumas Vaižgantas, Keletas Maironies būdo bruožų, [w:] Vaižgantas, Raštai, Kaunas 1933, t. 19.

17 Maironis, Paskaita apie Vysk. Ant. Baranauska, [w:] Maironis, Raštai, t. III, Vilnius 1992, s. 750. 
Tumas w swoich pismach dodaje, że Baranauskas krytycznie ocenił pracę, będąc bowiem zwolennikiem tradycji jagiellońskiej, nie mógł zaakceptować narodowej wymowy utworu ${ }^{18}$.

Poemat Lietuva Maironis napisał prawdopodobnie w roku 1888. Dzieło nie jest datowane. Utwór pozostał w rękopisie i tylko fragment został wydrukowany dopiero w 1891 roku w piśmie „Varpas”. Rękopis zaginął w bibliotece Antanasa Baranauskasa i dopiero staraniem Tumasa Vaižgantasa został ocalony i przekazany do Muzeum Kultury w Kownie (Kulturos Muziejus Kaune) ${ }^{19}$.

Poemat rozpoczynają słowa:

Tève mūsų tèvynès!

Mūsų ryto žvaigždelè !

Būk pagarbints, pramynęs

Mums kaip milžinas kelią! ${ }^{20}$

Ojcze naszej Ojczyzny!

Gwiazdo naszego poranka!

Bądź pochwalony,

Ty, który jak dzielny rycerz wskazywałeś nam drogę!

...i dedykacja skierowana do biskupa Baranauskasa:

Jo Mylistai, Šviesiausiam Vyskupui Antanaui Baranauskui21.

(Do Najjaśniejszego, Łaskawego Biskupa Antanasa Baranauskasa)

Utwór przez badaczy literatury uważany jest za ważny historyczny dokument, pokazujący nastawienie i zapatrywania kształtującej się młodej inteligencji litewskiej, w szczegółowym opisie ziem litewskich przyrównywany jest do Pieśni o ziemi naszej Wincentego Pola, w tekście nie brak odniesień

18 R. Mikšytè, Baranauskas ir Maironis, [w:] Literatūra ir kalba, t. XXI, Vilnius 1990, s. 163 .

19 Maironis, Raštai, t. II, Vilnius 1992, s. 501.

20 Tamże, s. 292.

21 Tamże, s. 292. 
nie tylko do Baranauskasa: ,[...] Ten Baranauskas giesmes mastabo” (Tam Baranauskas pieśni układał), „[...] Ten tai Šventoji, ką giesmių savo vyskupo klausès" (Tam jest rzeka Święta, która pieśni swojego biskupa słucha), ale też do utworu Metai Kristijonasa Donelaitisa, do postaci Adama Mickiewicza , $[. .$.$] čionai didžiausias tarpo poetu, garsus Adomas išvydo svietą” (tam$ największy wśród poetów, sławny Adam na świat przyszedł), a zakończenie tworzy parafraza słów opisujących Witolda, zaczerpniętych z utworu Józefa Ignacego Kraszewskiego Wilno od początków jego do roku $1750^{22}$.

Jak już zostało wspomniane, w 1888 roku rozpoczął Maironis studia w Akademii Duchownej w Petersburgu. Analizował pisma Goethego, Schillera, Puszkina, ale wydaje się, że najważniejszym poetą nadal był Adam Mickiewicz. Zaborskaitè przyznaje, że

[...]seminarijos laiku J. Mačiulị galima būtu sieti pirmiausia, sakytume, su epiniais A. Mickevičiaus kūrybos momentais, jo sukurtu Lietuvos paveikslu, o dabar jam ryškiau atsiveria žmogiškoji Mickevičiaus problematika, jo duodamas individo ir visuomenès, žmogaus asmeninès laimès ir visos tautos laimés santykio sprendimas 23 .

([...]w czasie nauki w seminarium [upodobania] Maironisa można by przede wszystkim wiązać z epickimi pierwiastkami w twórczości Mickiewicza, ze stworzonym przez niego obrazem Litwy, a obecnie wyraźniej objawiła mu się ludzka strona twórczości Mickiewicza, postawiony przez niego problem jednostkowego i zbiorowego szczęścia, osobistego szczęścia człowieka i szczęścia całego narodu.)

Ciekawostką czytelniczą ze studenckiego okresu fascynacji literackich Maironisa, na którą badacze literatury litewskiej niezbyt zwracają uwagę, jest ulubiona lektura poety i to nie romantyczne, a pozytywistyczne dzieło - Charakter angielskiego pisarza Samuela Smilesa ${ }^{24}$.

22 Maironis, Lietuva, [w:] Maironis, Raštai, t. II, Vilnius 1992, s. 292-343.

23 Tamże, s. 77.

24 The charakter-Charakter ukazał się w „Kłosach”w 1873 roku w przekładzie Lubowskiego, a następnie w 1879 roku w thumaczeniu Przyborowskiego. Patrz: Enc. S. Orgelbranda, t. XIII, Warszawa 1902. Maironis mógł czytać Smilesa w thumaczeniach na język rosyjski. 
W Polsce Smiles znany był i uwielbiany od końca lat sześćdziesiątych ze względu na utwór Self-help - Pomoc własna (1859), a Charakter był dalszą jej częścią. Dlaczego właśnie to laickie dzieło o typowo pozytywistycznym wydźwięku - złożone z charakterystyk ludzi polegających na własnych siłach, ceniących oszczędność, obowiązkowość i praktycyzm na stałe zagościło w sercu księdza i poety? Różne są zdania na ten temat badaczy twórczości Maironisa.

Zaborskaitė thumaczy to następująco:

Greta puslapiu, skelbančiu lèkštoką didaktiką ir labai jau bendras tiesas, J. Mačiulis galèjo čia rasti ir tokiu teiginiu, kurie buvo artimi jo paties gyvenimo koncepcijai. Jie, tiesa, neatvère jam nieko naujo - tuos pačius dalykus jis buvo godžiai gèręs iš Mickevičiaus ir Šilerio poezijos. Bet jie atitiko jo paties dvasinę struktūrą, polinkius, [sitikimus, skambejo kaip kažkas labai sava ir džiugino ne naujumu, [...], o patvirtindami tai, kas jau ankščiau ir kitur surasta bei laimèta ${ }^{25}$.

(Oprócz akapitów pełnych płytkiej dydaktyki i powszechnie uznanych prawd, Mačiulis mógł tutaj znaleźć i takie twierdzenia, które bliskie były jego własnej koncepcji życiowej. Oczywiście twierdzenia te nie wnosiły nic nowego, tych samych rzeczy chciwie nałykał się z poezji Mickiewicza i Schillera, ale odpowiadały one jego własnej strukturze wewnętrznej, skłonnościom, brzmiały jak coś własnego i cieszyły nie nowością [...], ale tym, że potwierdzały coś, co już wcześniej, gdzie indziej było [przez niego] odkryte i osiągnięte.)

Wydaje się, że Zaborskaitè nieco spłyciła zagadnienie i ominęła trudność, jaką stwarza dla badacza twórczości Maironsa zamiłowanie poety do tej pozytywistycznej pozycji, zdradzające przecież, że albo nie zauważał, albo bagatelizował on sprzeczność pomiędzy cenionymi przez siebie wartościami. Nie można zapominać, że książka ta po 1867 roku była bardzo chętnie czytana, że stała się, jak mówi Jolanta Sztachelska, ,językiem epoki”, podręcznikiem wyrażającym zapatrywania pozytywistów ${ }^{26}$. Według tej autorki o ogromnym

25 V. Zaborskaite, dz. cyt., s. 79.

26 J. Sztachelska, Czytanie Smilesa, [w:] Książka pokolenia, red. E. Paczoska i J. Sztachelska, Białystok 1994, s. 79. Książki Samuela Smilesa były wręcz rozchwytywane. Pierwsze wydanie angielskie miało aż 18 edycji. Self-help Smilesa wydrukowane zostało w 1867 roku w „Przeglądzie Tygodniowym”, czasopiśmie torującym sobie dopiero drogę w środowisku 
sukcesie Smilesa zadecydowało to, iż opisywał on swoich bohaterów jako postaci wyjątkowe, łamiące bariery przynależności stanowej czy klasowej, silne, wierzące we własne możliwości i talenty. Szkocki pisarz w swoim dziele wielokrotnie podkreślał takie cnoty jak praktycyzm, oszczędność, odwaga, wytrwałość w dążeniu do celu. Wierzył w postęp i uważał, że każdy powinien rozwijać samego siebie. Cenił ludzi czynnych, energicznych, a co ciekawe, jako wzór do naśladowania stawiał dwóch romantycznych twórców - Goethego i Scotta, którzy byli bardzo bliscy Maironisowi, zanim jeszcze poznał Smilesa. Przede wszystkim jednak Mačiulisa ująć musiało twierdzenie, iż:

[...] podstawą obywatelstwa są ludzie charakteru [...] szlachetna i prawa jednostka, uczciwie wypełniająca swe społeczne i narodowe powinności, może przez pracę własną przyczynić się do odrodzenia i rozwoju swego kraju²7.

To samo przeświadczenie, które na pewno podtrzymywało nadzieję na niepodległość, znalazło wyraz w wielu wierszach Maironisa. Nie można się więc dziwić litewskiemu autorowi, że szukał otuchy w modnym w środowiskach postępowych piśmiennictwie, można się natomiast dziwić przyszłemu księdzu, że sięgnął w tym celu do literatury, która nadzieję zamykała w sferze przyrodzonych, utylitarnych wartości. Zalecenia Smilesa dawały się wprawdzie jakoś pogodzić z zasadami wiary, ale tylko wskutek zatarcia wyrazistości jednych i drugich. Rodzi to podejrzenia, że również wiarę wyznawał Mačiulis utylitarystycznie, tj. z uwagi na jej moralną użyteczność, a i z romantyzmu wybierał wartości łagodne, bliższe raczej biedermeierowi czy też upodobaniom etycznym oraz estetycznym literatury krajowej28. Do wniosków tych należałoby podejść z całą powagą i skrupulatnością, gdyby nie to, że Maironis nie był ideologiem czy teoretykiem, ale praktykiem zarówno jako poeta, jak i kapłan. Weryfikacji za to wymaga rozpowszechniony w literaturze sąd, iż poezja Maironisa jest poezją romantyczną i to jest dosyć

prasy warszawskiej. Ukazało się prawie równocześnie z takimi cenionymi pozycjami jak $\mathrm{Hi}$ storia cywilizacji Thomasa Buckle'a czy Filozofia sztuk pięknych Hipolita Taine'a. Wersja polska tego utworu była spolszczeniem niemieckiego thumaczenia Józefa Boyesa (tamże, s. 80).

27 Tamże, s. 82.

28 W. Żmigrodzka, Polska powieść biedermeierowska, „Pamiętnik Literacki” 1966, z. 2. 
odważnie postawiona teza, którą warto przedyskutować w kręgach badaczy literatury litewskiej.

Pracę dydaktyczną wykładowcy rozpoczął w 1892 roku w seminarium w Kownie, potem w Akademii w Petersburgu i ponownie w Kownie. Pochłaniała mu ona wiele czasu, a Maironis był zawsze bardzo sumienny i zaangażowany w to, co robił. W pracy zawsze korzystał z własnoręcznie napisanego skryptu i wymagał kategorycznie, aby uczniowie znali go prawie na pamięć29. Lubił w czasie wykładów o literaturze posługiwać się cytatami, a przytaczał je w oryginalnej wersji językowej: niemieckiej, polskiej, rosyjskiej ${ }^{30}$. Niezmierną wagę przykładał do sposobu wysławiania się, nie znosił błędów gramatycznych i stylistycznych, cenił sobie elegancję w mówieniu ${ }^{31}$. Przeciwny był wtrącaniu do języka litewskiego zapożyczeń, choć i w jego wypowiedziach natrafia się na użycie obcych form leksykalnych i gramatycznych.

Maironis był zżyty z dziełami kanonicznymi, swoim wychowankom więc zalecał przede wszystkim lekturę Homera i Dantego ${ }^{32}$. Nie lubił i nie rozumiał literatury nowoczesnej, prądów nowatorskich, futuryzmu i awangardyzmu, które, przeżywając swój rozkwit na Zachodzie, trafiały również do międzywojennego Kowna. Czytając relacje z wykładów, można jednak odnieść wrażenie, że Maironis częściej wchodził w polemikę z prądami, które zdobywały sobie publiczność w czasie, w którym i jemu zależało na zdobyciu „rządu dusz”:

Pasaulinèje literatūroje Maironis laikèsi klasikinès estetikos kriteriju. Todèl suprantama, kad, kalbèdamas apie naują pasaulinę literatūra smerkè simbolizmą. Simbolizmas, sakè Maironis, siekdamas vis didesnio neaiškumo, nustoja pagaliau turinio, persimeta i vienpusišką dekadentizmą, ieškojimą vien nauju išviršiniu formu, harmoningo garsu suderinimo, jų ritmikos net be vidinès prasmès, kad tik sukeltų tam tikrą ūpą ${ }^{33}$.

(Mówiąc o literaturze powszechnej, Maironis trzymał się klasycznych kryteriów estetycznych. Toteż rzecz zrozumiała, że mówiąc o nowej literaturze powszechnej,

29 Z. Kuzmickis, Maironis, Vilnius 1990, s. 627; Literatūra ir kalba, t. XXI.

30 A. Tyruolis, Maironis, Vilnius 1990, s. 632; Literatūra ir kalba, t. XXI.

31 S. Būdavas, Maironis, Vilnius 1990, s. 520; Literatūra ir kalba, t. XXI.

32 Tamże, s. 521.

33 A. Lapè, Maironis, Vilnius 1990, s. 520; Literatūra ir kalba, t. XXI. 
potępiał symbolizm. Symbolizm, mówił Maironis, w dążeniu do coraz to większej niejasności, zatraca w końcu treść, wyradza się w jednostronny dekadentyzm, poszukiwanie coraz nowszych zewnętrznych form, harmonijnego zestrojenia głosów tylko po to, by dać pewien nastrój).

Nie ulega kwestii, że niechęć do symbolizmu w jego dekadenckim wydaniu nie mogła budzić żywszych emocji na początku lat dwudziestych, kiedy to właśnie niejako od drugiej strony stał się on przedmiotem ataku ze strony piewców dwudziestego wieku. O dziwo Maironis cenił niektórych autorów związanych z symbolizmem, przepowiadał bogatą przyszłość poetycką Vincasowi Mykolaitisowi Putinasowi, Liudasowi Girze i Mykolasowi Vaitkusowi.

Zresztą rozbudzona już w dzieciństwie ciekawość świata powodowała również i to, że Maironis czytał praktycznie wszystko, co w tym czasie ukazało się na Litwie. Pozostaje zagadka czy radził sobie z dziełami francuskimi, niemieckimi w oryginalnej wersji, ale bogate zbiory biblioteczne pokazują, że cześć z wydań obcojęzycznych była nietłumaczona.

Ciekawa zresztą jest historia zbiorów bibliotecznych Maironisa. Wiadomo, że część pozycji zaginęła w czasie I wojny światowej, kiedy poeta musiał opuścić Kowno, zostawić dom z całym wyposażeniem. Mykolas Vaitkus podaje, że poeta nie miał sił i zapału, aby uzupełniać braki po utraconych pozycjach księgozbioru i gromadzić nowe książki, dlatego biblioteka Maironisa nie odzyskała świetności ${ }^{34}$.

Istnieje katalog sporządzony przez Genovaitė Navašinskienè, w którym zarejestrowane są wszystkie należące do Maironisa książki przechowywane obecnie w zbiorach muzealnych ${ }^{35}$. Autorka wymienia 489 pozycji, przede wszystkim w języku litewskim, ale także po rosyjsku, po łacinie, po francusku, po niemiecku i po polsku. Wiele z nich to książki o tematyce religijnej - katechizmy, zbiorki pieśni kościelnych, modlitewniki. Wśród dzieł rodzimej literatury znaleźć można prace Motiejusa Valančiusa (Macieja Wołonczewskiego), Juozasa Tumasa-Vaižgantasa, Juozapasa Albinasa Herbačiauskasa (Józefa

35 G. Navašinskienè, Maironis, Vilnius 1990, s. 686-736; Literatūra ir kalba, t. XXI. 
Albina Herbaczewskiego), Liudasa Giry i Jonasa Žiliusa-Jonily. Brakuje cenionego przez poetę Borku oniksztyńskiego Antanasa Baranauskasa, jest za to unikalne studium matematyczne tego autora.

Brakuje również zbiorów Goethego i Schillera. Z literatury rosyjskiej miał pod ręką pisma Puszkina, Tołstoja i Gogola. Miał też oczywiście Homera i Dantego, jak też Szekspira oraz Ibsena.

Najwięcej chyba jednak zastanawia zbiór książek polskich autorów. W bibliotece Maironisa znajdowało się około 80 pozycji napisanych lub przetłumaczonych na język polski, przy czym w większości były to podręczniki do nauki religii, przykłady kazań, nauk kościelnych, żywoty świętych. Trzeba uznać, że większość ciekawych dla badacza literatury pozycji zaginęło i trudno obecnie na podstawie tego, co pozostało, określić gusty literackie Maironisa czy potwierdzić przypuszczenia co do nich. Nie zachował się na przykład żaden, choćby cienki zbiorek Mickiewicza, co świadczy bez wątpienia o tym, jak bardzo zbiór jest niekompletny. Są za to Pisma Juliusza Słowackiego w wydaniu z 1900 roku z przedmową Piotra Chmielowskiego, dwie powieści Bolesława Prusa: Lalka i Faraon. Spis nie odnotowuje więcej dzieł literatury pięknej, znajduje się w nim natomiast komplet Dziejów starożytnych narodu litewskiego Teodora Narbutta, Kronika Polska, Litewska i Żmudzka Macieja Stryjkowskiego oraz Kronika Wielkiego Księstwa Litewskiego i Żmudzkiego, wydana przez Stanisława Ptaszyckiego według rękopisu z 1550 roku.

Poniekąd wbrew ogólnemu przekonaniu Maironis nie pisał wiele. Na ogół wypowiadał się w druku na tematy historycznoliterackie, o których przecież wykładał, nie ogłaszał też raczej krytycznych analiz poezji. Opublikował „konspekt historyczny” (taką nazwę podaje sam autor) Trumpa visuotinès literatūros istorija (Krótka historia literatury powszechnej) dotyczący historii literatur Azji i Afryki (chińskiej, japońskiej, perskiej, arabskiej, asyryjskiej), a także literatur małych narodów (łotewskiej, białoruskiej, fińskiej). Może te literackie fascynacje wpłynęły na to, że poeta w zbiorku Pavasario balsai drukowanym w 1927 roku zamieścił sporo tłumaczeń (głównie zresztą przekłady z hinduskich pieśni Rigwedy). W wydaniu tym znalazło się również tłumaczenie poematu Cauripancaśikha (Pięćdziesiąt strof o rozkoszach miłości), napisanego w sanskrycie przez XI-wiecznego poetę kaszmirskiego Bilhana. Może budzić pewne zdziwienie fakt, że osoba duchowna zajmowa- 
ła się poezją, która tak bezpośrednio mówiła o perypetiach miłosnych poety i księżniczki36. Do wyjątków należą artykuły o Donelaitisie, o Baranauskasie, o których wspomniane było już wcześniej.

Nie można zaprzeczyć, że właśnie Mickiewicz, nie Baranauskas czy Donelaitis, pozostał dla Maironisa na całe życie pierwszym, ukochanym poetą. Jego wpływ wyraźnie zaznaczona się w kilku utworach litewskiego autora, między innymi w poemacie Jaunoji Lietuva, balladzie Čičinskas wzorowanej na mickiewiczowskim utworze Popas w Upicie, w wierszu Užtrauksme nauja giesmę, będącym litewską Oda do Młodości.

Zresztą nie tylko dla Maironisa, ale i dla większości autorów litewskich końca XIX wieku, licząc od początku ruchu odrodzenia narodowego i kulturalnego, poezja Mickiewicza była przedmiotem admiracji. Pomimo zanegowania tradycji jagiellońskiej młoda inteligencja litewska z Mickiewicza uczyła się litewskich dziejów i miłości do ojczyzny. Sądy podkreślające zauroczenie Maironisa twórczością Mickiewicza formułuje w artykule Didysis lenku poetas ir lietuviu literatūra Vincas Mykolaitis Putinas. Można tam między innymi przeczytać, że:

Maironis dar jaunystèje parašytoje poemèlèje Lietuva vadina Adomą Mickievičiu didžiausiu tarpe poetu, gérisi, kad jis mylèjo tèvynę. Maironis gerai pažino A. Mickievičiaus poeziją. Paties Maironio kūryboje pastebime ir A. Mickievičiaus poezijos poveiki ${ }^{37}$.

(Maironis w krótkim poemacie Litwa, napisanym jeszcze w młodości, nazywa Adama Mickiewicza „największym spośród poetów”, zachwyca się tym, że ukochał on ojczyznę. Maironis dobrze poznał poezję Mickiewicza. W twórczości Maironisa zauważamy wpływy poezji Mickiewicza.)

Maironis w wielu swoich dziełach powoływał się na tego wieszcza, zawsze pozytywnie wypowiadał się o jego dziełach i wpływie, jaki wywarły one na kształtowanie się zapatrywań narodowych i wyzwoleńczych rodaków.

Co ciekawe mickiewiczowską pieśń z Konrada Wallenroda - Wilija, naszych strumieni rodzica, włączył w tom wierszy Pavasario balsai.

36 L. Frederic, Stownik cywilizacji indyjskiej, Katowice 1998, s. 143.

37 V. Mykolaitis Putinas, Didysis lenkų poetas ir lietuvių literatūra, „Literatūra ir menas” 1955. 
Wiliję, tak jak i cały utwór Mickiewicza, na Litwie nadzwyczaj chętnie czytano.

Dokonywano wielokrotnie thumaczeń Wiliji na język litewski, ale uważa się, że przekład Maironisa jest najlepszy ${ }^{38}$. Poeta pierwszy raz opublikował własne tłumaczenie Mickiewiczowskiej pieśni w 1891 roku w Tylży w piśmie „Žemaičių ir Lietuvos apžvalga” („Przegląd Żmudzki i Litewski”) ${ }^{39}$. To wydanie zostało podpisane przez poetę pseudonimem Maironis, w podtytule dodana była informacja: Iš Mickaus: Konrad Wallenrod (Z Mickusa: Konrad Wallenrod) ${ }^{40}$. Kolejne przekłady ukazywały się we wszystkich wydaniach zbiorku wierszy $P a$ vasario balsai. W pierwszym wydaniu z 1895 roku i drugim z 1905 roku pieśń Wilija zapisana została na drugim miejscu, w następnym z 1913 roku nastąpiło przesunięcie na czwartą pozycję, a z 1920 roku na piątą. W ostatniej publikacji, wydanej za życia poety w 1927 roku, już nie jako zbiorek liryków, ale pierwszy tom Pism zebranych, thumaczenie utworu Mickiewicza umieszczone zostało przy samym końcu i zginęło w natłoku innych wierszy. Równocześnie w nawiasie podana została przez Maironisa litewska nazwa rzeki „Neris”, a w podtytule „Versta iš Mickievičiaus” („Tłumaczona z Mickiewicza”). Ma się wrażenie, że w ostatnim wydaniu rola i waga tego utworu w porównaniu z innymi lirykami stopniowo zmalała, ale też pozycja Maironisa jako fundatora poezji litewskiej była już ugruntowana. Mimo zamiaru Maironisa, by odsunąć uwagę publiczności od pieśni i zwrócić ją w kierunku innych wierszy, popularność utworu nie słabła; przekład był wielokrotnie wznawiany i przedrukowywany ${ }^{41}$.

Trzeba przy okazji zauważyć, że Maironis ciągle pracował nad thumaczeniem. Tekst pierwszego wydania zasadniczo różni się od ostatecznej redakcji. Zmiany widać już na początku wydanego w 1891 roku przekładu, w którym wersy Mickiewicza:

38 Wilię Adama Mickiewicza tłumaczyli między innymi: Valerijonas Ažukalnis-Zagurskis, Jonas Žilius-Jonila, Stanislovas Dagilis, Juozas Brazaitis, Vincas Kudirka, Jonas MačysKèkštas, Vincas Mykolaitis-Putinas. Patrz: M. Jackiewicz, dz. cyt., s. 88.

39 To wydanie zostało podpisane przez poetę pseudonimem Maironis, w podtytule dodana była informacja: Iš Mickaus: Konrad Wallenrod (Z Mickusa: Konrad Wallenrod). Patrz: Maironis, Vilija, „Žemaičių ir Lietuvos apžvalga” 1891, nr 10, s. 78.

40 Maironis, Vilija, „Žemaičių ir Lietuvos apžvalga” 1891.

41 Szczegółowy spis kolejnych wydań Wilii Adama Mickiewicza w przekładzie Maironisa podaje w swojej książce profesor Mieczysław Jackiewicz. Patrz: M. Jackiewicz, dz. cyt., s. 269. 
Wilija naszych strumieni rodzica,

Dno ma złociste i niebieskie lica; ${ }^{42}$

...zyskują postać:

Vilija - mūsų šaltinių matutè,

Veidas jos melsvas ir dangus auksinis; ${ }^{43}$

Wilija - mateczka naszych źródeł,

Twarz jej błękitna i niebo złote;

W ostatniej publikacji, z roku 1927 tłumaczenie jest poprawione i uściślone:

Vilija, mūsų upelių matutè,

Dugną tur aukso, o veidą kaip dangu; ${ }^{44}$

Wilija, mateczka naszych rzek,

Dno ma złociste, a twarz jak niebiosa;

Jak zauważają badacze litewscy, echa Wiliji pobrzmiewają w niektórych utworach litewskiego poety. Pewnych analogii można doszukać się w IV pieśni poematu Tarp skausmu i garbę (Przez męki do chwały), a także w IV pieśni poematu Jaunoji Lietuva (Młoda Litwa).

W utworze Mickiewicza Wilija „gardzi doliny kwiatami, bo szuka Niemna swego oblubieńca"45, za to Litwince dokucza nuda między Litwinami, jako że myśli jej wybiegają do ukochanego „cudzego młodzieńca”46.

42 A. Mickiewicz, Konrad Wallenrod, [w:] tenże, Dzieła, t. II, Warszawa 1997, s. 82.

43 Maironis, Vilija, „Žemaičių ir Lietuvos apžvalga” 1891, nr 10. Bardzo prawdopodobne, iż „dangus” zostało wprowadzone zamiast podobnego brzmieniowo „dugnas” wskutek pomyłki wydawcy.

44 Maironis, Vilija, [w:] Raštai, T. II, Vilnius 1988.

45 A. Mickiewicz, Konrad Wallenrod i Grażyna, Paryż 1851, s. 29.

46 Tamże, s. 29. 
Paralelnie w liryku Maironisa w pięknej rzece Dubissie kocha się stojące na brzegu drzewo, brzoza; po litewsku „beržas” ma rodzaj męski. Niestety Dubissie tęskno do ukochanego Niemna. Inaczej niż w utworze Mickiewicza przedstawiona jest rola Litwinki: oczywiście nie szuka ona już obcego młodzieńca, tylko cierpliwie czeka na swojego Litwina, który jednakowoż jest daleko.

\author{
Lietuvės neieško kaip vilnys Dubysos \\ Sau meilès už kalnu, už giriu tamsių; \\ Bet meilę ir širdi atranda ne visos, \\ nes bèga lietuviai nuo ju. \\ Lietuvès, kur vilnys Dubysos banguoja, \\ Sau rūtomis pina geltąsias kasas; \\ Kad pradalges grèbia, griaudžiai uždainuoja, \\ bet širdi ju kas besupras? ${ }^{47}$
}

W tłumaczeniu Stefanii Jabłońskiej:

Miłość Litwinek nie sięga za morze,

Za ciemne lasy, jak Dubissy fala!

Lecz znaleźć miłość - nie każda z nich może,

Litwini bowiem są z dala.

A więc Litwinki na brzegach Dubissy,

Warkocze w rutę przystroiły ładnie;

Rzewną ich piosnkę wędrowiec usłyszy,

lecz któż ich serca odgadnie? ${ }^{48}$

Maironis nadał swojemu utworowi silnie patriotyczny wydźwięk, wchodząc nawet w swego rodzaju polemikę z Mickiewiczem. Nie jest to już tylko

47 Tenże, Jaunoji Lietuva, [w:] Raštai, t. II, Vilnius 1988, s. 44.

48 Tenże, Młoda Litwa, z litewskiego tłumaczyła St. Jabłońska, Wilno 1920, s. 31. 
pieśń o miłości, ale utwór zawierający w sobie ideę wierności i miłości do ojczyzny, jak też mówiący o niedoli ukochanego kraju. Szczególnie widać to w ostatniej zwrotce:

\author{
Kaip rausta jurginai ir rūtos žaliuoja \\ Ir pina Dubysos pakrančius margai, \\ Taip žydi lietuvès, bat liūdnai dainuoja, \\ nes spaudžia ju šali vargai ${ }^{49}$. \\ Jako te kwiaty, które ozdabiają \\ Ponad Dubissą położone pola - \\ Kwitną Litwinki, lecz smutno śpiewają, \\ Gdyż kraj ich tłoczy niedola 50 .
}

Końcowa strofa różni się zasadniczo od Mickiewiczowskiej, która wprowadza w wypadki Konrada Wallenroda, w których Aldona, zamknięta w wieży, dalej czeka na ukochanego:

Serce i potok ostrzegać daremnie,

Dziewica kocha, i Wilija bieży;

Wilija znikła w ukochanym Niemnie,

Dziewica płacze w pustelniczej wieży ${ }^{51}$.

Podobne patriotyczne i antypozytywistyczne przesłanie w pieśni o Dubissie odczytał Vincas Mykolaitis Putinas. W pracy zatytułowanej Adomas Mickievičius ir lietuviu literatūra autor pisze, że:

Mickievičiaus Viliją Konrado Valenrodo poemoje dainuoja Albanas, noredamas išreikšti liūdną Aldonos likimą, ir poetui nerūpèjo duoti šiai dainai platesnès aktualios visuomeninès prasmès. Tuo tarpu Maironis turi galvoj aktualu aniems laikams lietuvišku šeimu klausimą ir priekaištauja to meto jauniems lietuvių inte-

49 Tenże, Jaunoji Lietuva, [w:] Raštai. t. II, Vilnius 1988, s. 44.

50 Tenże, Młoda Litwa, z litewskiego tłumaczyła St. Jabłońska, Wilno 1920, s. 32.

51 A. Mickiewicz, Konrad Wallenrod i Grażyna, Paryż 1851, s. 30. 
ligentams, kurie dažniausiai vesdavo svetimtautes. Taigi Mickievičiaus "Vilijos" motyvas Maironio kūryboje, veikiamas skirtingos epochos ir panaudotas skirtingam tikslui, igavo kitokią idejjinę prasmę ${ }^{52}$.

(W poemacie Konrad Wallenrod Mickiewicza Wilię wyśpiewuje Halban, chcąc wyrazić smutny los Aldony, poeta nie troszczył się, by nadać pieśni aktualnego, społecznego znaczenia. Równocześnie Maironis miał na względzie palącą w owych latach kwestię mieszanych małżeństw litewskich i występował przeciw młodym litewskim inteligentom, którzy poślubiali przedstawicielki innych narodów. Tak też motyw z Wilii Mickiewicza w twórczości Maironisa zastosowany do innej epoki i przeznaczony dla innych celów, nabierał odmiennego znaczenia ideowego.)

Mickiewiczowski wzór Maironis traktował jako wyzwanie. Widać to wyraźnie nie tylko dzięki wielorakim funkcjom, w jakich wykorzystał Wiliję, ale i w tym, że u początku swej drogi twórczej próbował nawiązać do poetyckich manifestów młodości wileńskiego wieszcza. Oda do młodości Mickiewicza stanowiła bez wątpienia źródło inspiracji dla Užtrauksme naują giesmę, znanej też przez wiele lat pod wcześniejszym autorskim tytułem Jaunimo giesmé ${ }^{53}$ (Pieśń młodości). Obydwa utwory akcentują przewagi młodości, jej siłę ducha, wiarę i optymizm. Podkreślają też wartość przyjaźni i miłości. Mickiewicz większy nacisk kładzie na problem wolności i wyzwolenia, Maironis za to nieco spokojniejszym tonem mówi o pracy i nauce, w czym widać pewien pozytywistyczno-asnykowski, a może i kudyrkowski nalot, choć pierwiastkiem dziejotwórczym u Maironisa jest nie sam postęp, tylko miłość do ludzi i ojczyzny, Litwy.

Obydwa zbliżone gatunkowo utwory stanowią rodzaj odezwy czy wezwania, mówią o tych samych wartościach, ale z innej perspektywy i jest to chyba najistotniejsza różnica między nimi. Podmiot liryczny w utworze Mickiewicza zwraca się bezpośrednio do personifikowanej „młodości”. Ponadto, utożsamia się on z młodymi ludźmi i te hasła, które formułuje, są równocześnie drogo-

52 V. Mykolaitis Putinas, Adomas Mickievičius ir lietuviu literatūra, Vilnius 1955, s. 74-75.

53 Dopiero w ostatnim z 1927 roku utwór ten zapisany jest po tytułem Užtrauksme nauja giesmę. Wcześniej znana była nazwa Jaunimo giesmé. Patrz: Maironis, Užtrauksme nauja giesmę, [w:] Raštai, t. I, Vilnius 1988, s. 271. 
wskazami dla niego samego. Inaczej zbudowany jest utwór Maironisa, gdyż podmiot liryczny wypowiada się z pozycji nauczyciela, poeta zwraca się do swoich przyjaciół, swoich braci, tych jemu równych, ale dysponuje on większą od nich wiedzą. Nawołuje, aby zarzucili oni stare poglądy i spojrzeli na rzeczywistość z innej perspektywy:

\author{
Užtrauksim naują giesmę, broliai, \\ Kurią jaunimas tesupras! \\ Ne taip giedosme kaip lig šiolei: \\ Kitas mąstysime dūmas ${ }^{54}$. \\ Pociągnijmy nową pieśń, bracia \\ Którą zrozumieć ma młodzież! \\ Nie tak śpiewajmy jak do tej pory \\ Inne rozważmy myśli.
}

Można te wersy odczytać również w inny sposób:

[...] tame šūkyje išsakyta visa: ir jaunu kovotoju solidarumas, ir pasitikèjimas savo jejgomis, ir [sitikinimas, jog tik jaunimas tebus naujos ateities kūrejas" ${ }^{\prime 5}$.

(W tej odezwie wyrażone jest wszystko: i solidarność młodych bojowników, i wiara we własne siły, i przeświadczenie, że tylko młodzież będzie twórcą nowej przyszłości).

Wszyscy działacze społeczni i polityczni Odrodzenia Litewskiego, w tym Maironis, mający w momencie ukazania się wiersza, tj. w 1895 roku, trzydzieści trzy lata, mogli uważać się za adresatów Pieśni ${ }^{56}$. Jednoznacznie więc ten utwór osadzony jest w konkretnym kontekście historycznym. Maironis powtarzał więc w stosunku do pierwszego pokolenia narodowej inteligencji litewskiej to, co Mickiewicz wyrażał jako głos pierwszego po-

54 Maironis, Raštai, t. I, Vilnius 1988, s. 105.

55 V. Zaborskaitè, dz. cyt., s. 128.

56 Tamże, s. 128. 
kolenia inteligencji dawnego Wielkiego Księstwa ${ }^{57}$. Idąc tym tropem można zaryzykować twierdzenie, iż Maironis po latach dzielących jego epokę od filomackiej „balladomanii” 58 próbował swych sił na tym polu twórczości. W zbiorku Pavasario balsai znalazł się między innymi wiersz Šatrijos kalnas (Góra Szatryjska), który badacze uznają za napisany pod wpływem Świtezi Mickiewicza ${ }^{59}$, choć, jak wiadomo, balladę na ten sam temat napisał przed Mickiewiczem również Jan Czeczot. W Šatrijos kalnas pierwiastek narracyjny i motywy fantastyczne mają silną przeciwwagę w opisowości, która pozwala zaznaczyć pożądany przez autora dystans do pogańskiego świata. Niemniej zależność od Świtezi jest nieskrywana, ba, eksponuje ją już pierwsza strofa ułożona w rytm „Ktokolwiek będziesz w Nowogródzkiej stronie":
I Žarènus miškais nuo Šiauliu Jei pro Luokę kada bekeliausi, Nepamiršk sustabdyti arklių Ir ten kalną užlipti aukščiausi ${ }^{60}$.
Jeżeli z Szawel do Żoren lasami Poprzez Łukniki będziesz podróżował, To nie zapomnij zatrzymać koni I tam na górę wspiąć się wysoką.

Ścisłe związki łączą utwór Maironisa pt. Čičinskas (Siciński) i Popas $w$ Upicie. Przede wszystkim wiąże je podobieństwo gatunkowe, jako że oba utwory to ballady. Mickiewicz co prawda określił swój wiesz jako ,powiastkę", ale zgodnie z użyciem tego słowa we wstępie do wydania Ballad i romansów z 1822 roku „powiastka” to szczególny rodzaj ballady - ballada na wzór „brytański”, „[...] osnowana z wypadków życia pospolitego albo

57 O filomatach jako o pierwszym pokoleniu inteligencji wielkoksiążęcej pisała Alina Witkowska: Rówieśnicy Mickiewicza. Życiorys jednego pokolenia, Warszawa 1998.

58 Por. tamże, s. 255.

59 M. Jackiewicz, dz. cyt., s. 144.

60 Maironis, Raštai, t. I, Vilnius 1988, s. 201. 
z dziejów rycerskich, ożywiona zwyczajnie dziwnością ze świata romantycznego, opiewana tonem melancholijnym, w stylu poważna, w wyobrażeniach prosta i naturalna" 61 .

W obydwu utworach współistnieją w sposób charakterystyczny dla „ballady romantycznej” elementy nadprzyrodzonej poetyczności, historia oparta o zdarzenie z dziejów szlacheckich oraz wypowiedzi w języku potocznym. Fabuła przedstawiona jest skrótowo, pojawiające się w utworach dialogi podkreślają dramatyczne cechy dzieła, ale pozycję dominującą zajmują czynniki liryczne. Podobieństwo formalne obu utworów jest bezwzględnie konsekwencją faktu, iż Maironis w Čičinskasie, podobnie jak Mickiewicz w Popasie w Upicie, sięgnął po ten sam historyczno-legendarny temat. Haniebny czyn posła Sicińskiego, zerwanie sejmowych obrad w 1652 roku i, jak dalej głosi podanie, jego tragiczna śmierć od pioruna na progu domu - stały się osnową obydwu utworów. Vanda Zaborskaitė uważa, że niezależnie od znajomości utworu Mickiewicza, poeta litewski mógł usłyszeć historię Sicińskiego jako opowiastkę gminną w czasie, kiedy mieszkał w Krakinowie i wielokrotnie jeździł z siostrą i przyjaciółmi Apolonii Petkaitė na wycieczki do Upity ${ }^{62}$. Wydaje się, że po raz kolejny podjął Maironis konkurencję z Mickiewiczem. Autorka dodaje jednak, że: „abiejų kūrinių pobūdis ir turinys skirtingi”63 (obydwa utwory różnią się charakterem i treścią). Nie można nie zgodzić się z tym zdaniem Zaborskaitè.

Jak wiadomo, w powiastce Mickiewicza narrator, tajemniczy podróżny, przedstawia osoby, które siedzą w karczmie i dyskutują, a każdy z biesiadników opisuje przewinienia już zmarłego, osławionego posła Sicińskiego. Zeznania ich są odmienne. Ksiądz mówi o zabranych dobrach kościelnych, marszałek o wyborach na sejmik poselski, ekonom przypuszcza, że sprawa dotyczy wojny i zdrady króla. Spór łagodzi przyjezdny. Stwierdza on, że:

O towarzysze! - rzekłem - pocoście niezgodni?

On był nie jednej winien, ale wszystkich zbrodni;

61 A. Mickiewicz, O poezji romantycznej, [w:] Idee programowe romantyków polskich. Antologia, oprac A. Kowalczykowa, Wrocław 1991, s. 54.

62 V. Zaborskaite, dz. cyt., s. 372.

63 Tamże, s. 372. 
Jego trucizną naród zdurzony oszalał;

On królom ręce związał, kraj klęskami zalał! ${ }^{64}$

Mickiewicz w duchu frenetycznym przedstawia obrazowo postać trupa, który nie może być pogrzebany, opisuje śmierć Sicińskiego, zalanie jego dóbr i spalenie domostwa. Morał opowiastki osłabiają zawarte w ostatniej, „cichej” wypowiedzi podróżnego wątpliwości co do roli, jaką może pełnić przekaz „gminny”, czym jest prawda historyczna i jak mijający czas oraz nawarstwiające się interpretacje zacierają wiarygodność każdego wydarzenia.

W utworze Maironisa czytelnik uczestniczy w balu, który odbywa się na dworze szlachcica Sicińskiego. Przedstawione są postacie ze świty posła (stańczyk Mantvydaitis, pasierb Bartkus, zezowaty niechluj Tiška). Kilkakrotnie autor opisuje postać Sicińskiego, jego zachowanie, nastroje. W dalszej części pokazuje podpalenie wsi w czasie rorat, wizytę zhańbionego posła w kościele i zabicie proboszcza. Przedmiotem szczegółowego opisu staje się też śmierć Sicińskiego na moście i zapadnięcie się dworu pod ziemię. Na końcu Maironis dodaje, że dusza złoczyńcy nie zaznała spokoju po śmierci i nawet ziemia „gynès! Mètè iš kapu [...] kuną” (,broniła się! Wyrzucała z grobu [...] ciało”) ${ }^{65}$. Čičinskas zachowuje jedność czasu i akcji w przeciwieństwie do powiastki Mickiewicza. Litewski poeta nie osłabia też moralnej wymowy utworu, jakkolwiek bowiem ludzie zapominają krzywdy i czas leczy rany, to przed Bożą sprawiedliwością nikt nie ucieknie i każdy ze swoich grzechów zostanie rozliczony. Maironis nie zapominał o swojej roli kapłana i pozostawał bardziej moralizatorem niż sceptycznym myślicielem.

Badacze twórczości Mickiewicza zauważyli - co trzeba przypomnieć dla dopełnienia obrazu analizowanej tu zależności obu poetów, że podczas studiów w Petersburgu Maironis przestał odbierać Mickiewicza jedynie jako piewcę dawnej Litwy, zwrócił natomiast uwagę na egzystencjalną wymowę tej poezji. Skoro tak, to obserwację tę warto odnieść najpierw do liryków lozańskich, których dotąd nie zestawiano z Pavasario balsai, choć przynajmniej jeden z wierszy do takiego zestawienia zaprasza. W wydaniu z 1905 roku pojawia się Vakaras ant ežero Keturiu Kantonu (Wieczór nad Jeziorem Czterech Kantonów), będący prawdo-

64 A. Mickiewicz, Wiersze, [w:] tenże, Dzieła, t. I, Warszawa 1993, s. 192.

65 Maironis, Čičinskas, [w:] Raštai, t. I, Vilnius 1988, s. 225. 
podobnie reminiscencją wrażeń po przebytej podróży do Szwajcarii. Wiersz ten uważany jest za jeden z najpiękniejszych. Čiurlionienė-Kymantaitè określiła go mianem „tikrai poezijos vaikas” (prawdziwie dziecko poezji) ${ }^{66}$. Wiersz odznacza się, co podkreślił Girdzijauskas, doskonałą formą poetycką. Mimo że każda strofa składa się tylko z czterech wersów, jego rytmika jest bardzo zróżnicowana ${ }^{67}$. Sama sytuacja liryczna - refleksja samotnego poety nad wodą w alpejskim pejzażu - nasuwa tu myśl o podobieństwie z takimi arcydziełami jak Nad woda wielka i czysta...W Wieczorze nad jeziorem czterech kantonów można odnaleźć podobny blask jak w lirykach lozańskich. Jak pisze Marian Stala, wynikać to może z tego, ,[...] iż one same są zapisami momentów olśnienia, iż mają strukturę widzenia, nagłego wewnętrznego odsłonięcia obrazu świata i miejsca w nim konkretnego, czującego i myślącego podmiotu"68.

Nasuwają się również inne odwołania, olśnienie pejzażem górskim - to z kolei jakby pogłos Na Alpach w Splügen - przenosi myśli i obrazy do młodości, nad rodzimą Dubissę. Tutaj wszakże w grę możliwych odwołań wchodzi również Gdy tu mój trup..., a także, nieoczekiwanie w tym kontekście poetyckim, $W$ Szwajcarii Słowackiego. Wszystkie one jakkolwiek wymagałyby analizy intertekstualnej i być może zagubiły fakt, iż Maironis łączy różne echa lekturowe w spójną, oryginalną formę i we wszystkich tych poetyckich próbach pozostaje bardzo maironisowski, niemożliwy do zaszufladkowania ani do żadnej epoki, ani prądu literackiego. Tomas Venclova zauważa:

Rašytojas pagal Maironi yra charizmatinè esybè, šauklys ir pilietis, pilnutinis ir harmoningas žmogus. Kaip mitinis mediatorius, jis suvienija priešingybes ir išsprendžia prieštaravimus.

(Pisarz według Maironisa staje się charyzmatyczną istotą, heroldem i obywatelem, spełnionym i harmonijnym człowiekiem. Jak mityczny mediator, łączy przeciwieństwa i rozwiązuje sprzeczności ${ }^{69}$.

66 Čiurlionienè-Kymantaitè, Dailès likimas. Dainos, [w:] Lietuviu literatūros kritika, t. I, Vilnius 1971, s. 390.

67 J. Girdzijauskas, Lietuviu eilèdara. Silabinès-tonines sistemos susiformavimas, Vilnius 1966 , s. 256.

68 M. Stala, Trzy nieskończoności. O poezji Adama Mickiewicza, Bolestawa Leśmiana i Czestawa Mitosza, Kraków 2001, s. 35.

69 Tamże, s. 288. 


\section{Bibliografia}

\section{Utwory Maironisa}

Maironio raštai: (5 t.). T. I, Lyrika. Eilèraščiai, fragmentai iš poemu, vertimai. - 6-asis leid. (5-asis Pavasario balsu leid.), Kaunas 1927.

Raštai, Lyrika, t. I, Vilnius 1988.

Raštai, Poemos, t. II, Vilnius 1988.

Raštai, Dramos, t. III, pirmoji knyga, Vilnius 1992.

Maironis, Apsakymai apie Lietuvos praeiga, [w:] Maironis, Raštai, t. III, Vilnius 1992.

Maironis, Jonas Ernestas Smoleris, [w:] Maironis, Raštai, t. III, Vilnius 1992.

Maironis, Paskaita apie Vysk. Ant. Baranauską, [w:] Maironis, Raštai, t. III, Vilnius 1992.

Maironis, Lietuva, [w:] Maironis, Raštai, t. II, Vilnius 1992.

Maironis, Čičinskas, [w:] Raštai, t. I, Vilnius 1988, s. 225.

Maironis, Vilija, „Žemaičių ir Lietuvos apžvalga” 1891, nr 10.

Maironis, Młoda Litwa, z litewskiego tłumaczyła St. Jabłońska, Wilno 1920.

\section{Pozostałe}

Adomavičius R., Maironio raštu bibliografija (1883-1989), Vilnius 1990.

Būdavas S., Maironis, Vilnius 1990, „Literatūra ir kalba“, t. XXI.

Čiurlionienè-Kymantaitè S., Dailès likimas. Dainos, [w:] Lietuvių literatūros kritika, t. 1, Vilnius 1971.

Frederic L., Słownik cywilizacji indyjskiej, Katowice 1998.

Girdzijauskas J., Lietuvių eilèdara. Silabinès-toninès sistemos susiformavimas, Vilnius 1966.

Jackiewicz M., Literatura litewska w Polsce w XIX i XX wieku, Olsztyn 1999.

Jackiewicz M., Literatura polska na Litwie XIV-XX wieku, Olsztyn 1993.

Kuzmickis Z., Maironis, Vilnius 1990, „Literatūra ir kalba“, t. XXI.

Lapè A., Maironis, Vilnius 1990, „Literatūra ir kalba“, t. XXI.

Mickiewicz A., Ballady i romanse, Paryż 1822, [w:] Słownik literatury polskiej XIX wieku, Wrocław 1991.

Mickiewicz A., Konrad Wallenrod i Grażyna, Paryż 1851.

Mickiewicz A., Oda do młodości, [w:] Wiersze i powieści poetyckie, Warszawa 1998 ,

Mickiewicz A., Popas w Upicie, [w:] Wiersze i powieści poetyckie, Warszawa 1998. 